\title{
In Vitro Evaluation of Fungicides against Aspergillus niger causing Collar Rot Disease in Groundnut (Arachis hypogaea L.)
}

\author{
Amritpal Singh Sekhon*, Prabhjodh Singh Sandhu, Pankaj Sharma and Rakesh Belludi
}

\author{
Department of Plant Pathology, Punjab Agricultural University, \\ Ludhiana, 141004, Punjab, India \\ *Corresponding author
}

\section{A B S T R A C T}

\begin{tabular}{l} 
Ke y w o r d s \\
Aspergillus niger, \\
$\begin{array}{l}\text { Fungicides, } \\
\text { Groundnut, Collar } \\
\text { rot, Potato dextrose } \\
\text { agar medium }\end{array}$ \\
Article Info \\
Accepted: \\
$\begin{array}{l}10 \text { October } 2019 \\
\text { Available Online: } \\
10 \text { November } 2019\end{array}$ \\
\hline
\end{tabular}

\section{Introduction}

Groundnut (Arachis hypogaea L.) is an important oilseeds and ancillary food crop in India with 7.4 million tonnes production from 4.7 million ha area and also has good export potential. India is the largest grower and second largest producer of groundnut after China with a national average productivity of about $1552 \mathrm{~kg} / \mathrm{ha}$ (Anonymous, 2015). Major groundnut growing states in India are Gujarat, Andhra Pradesh, Tamil Nadu, Karnataka, Rajasthan and Punjab. The productivity of groundnut in India is low in comparison to world average may be due to the damage caused by diseases and insect pests. Diseases cause considerable yield losses in groundnut. Fungal, virus and bacterial pathogens attack 
the crop at various stages of growth and cause severe yield losses and in some cases impairing quality (Subrahmanyam et al., 1980). The major soil borne diseases of groundnut caused by fungi are collar rot/crown rot/seedling blights (Aspergillus niger), stem rot/Sclerotium wilt (Sclerotium rolfsii Sacc.), alaroot (Aspergillus flavus) and dry root rot/dry wilt (Macrophomina phaseolina). Among all diseases, collar rot is reported to cause losses in yield up to $40 \%$ in India (Chohan, 1965). The losses may amount to $40-50 \%$ in terms of mortality of crop (Aulakh and Sandhu, 1970). In Gujarat, the incidence of seedling blight of groundnut was found as high as 50 per cent (Joshi, 1969).

Among various methods, fungicides serve as an important and efficient method to control collar rot disease caused by Aspergillus niger. From time to time, many workers made attempts to test the efficacy of different fungicides under invitro conditions. Wani and Kuruchave (2004) reported 100\% inhibition of mycelium growth of $A$. niger and $A$. flavus by thiram and (carbendazim + mancozeb) at 250 ppm concentration.

Sharma et al., (2012) observed that the carbendazim and mancozeb completely inhibited the mycelial growth of fungus at higher concentrations of 500 and 1000 ppm. Parjapati et al., (2016) studied the efficacy of different fungicides against $A$. niger under invitro conditions.

They found that carbendazim (12\%) + mancozeb (63\%), azoxystrobin (18.2\%) + difenconazole $(11.4 \%)$, trifloxystrobin $(25 \%)$ + tebuconazole $(50 \%)$ and mancozeb $(50 \%)+$ carbendazim (25\%) at 500 and $100 \mathrm{ppm}$ concentrations completely inhibited the mycelial growth of $A$. niger. Keeping these aspects in view, the present study was planned to evaluate the efficacy of different fungicides against $A$. niger under in vitro conditions.

\section{Materials and Methods}

The effect of six different fungicides namely mancozeb, tebuconazole, azoxystrobin, carbendazim, carbendazim $25 \%+$ mancozeb $50 \%$ (Sprint) and carboxin $37.5 \%+$ thiram $37.5 \%$ (Vitavax power) on the growth of $A$. niger was studied using Poisoned Food Technique and Paper Towel Method.

\section{Poisoned food technique}

Poisoned food assay (Nene and Thapliyal 1993) was employed to study efficacy of above mentioned fungitoxicants under lab conditions. Non-systemic fungitoxicant mancozeb was tested at a series of concentrations viz. 25, 50, 100, 200, 500 ppm, whereas systemic fungitoxicants (tebuconazole, azoxystrobin, carbendazim, carbendazim 25\% + mancozeb $50 \%$ and carboxin $37.5 \%$ + Thiram $37.5 \%$ ) were tested at series of concentrations viz. 25, 50, 100 and $200 \mathrm{ppm}$ respectively. Required quantity of the test chemical was mixed with $100 \mathrm{ml}$ of PDA sterilized medium and the poisoned medium was poured into Petri dishes $(90 \mathrm{~mm}$ diameter) under aseptic conditions. Circular bits $(7 \mathrm{~mm})$ of the actively growing culture of fungus were placed aseptically in the center of each Petri dish and each concentration was replicated four times. The Petri dishes with PDA medium without fungicide served as control. After inoculation Petri Plates were incubated at $25 \pm 1^{\circ} \mathrm{C}$. The radial colony growth of pathogen was recorded when the growth in untreated control plate was full (i.e. $90 \mathrm{~mm}$ ) and per cent inhibition in colony growth $(\mathrm{Pi})$ was calculated by using formula devised by Vincent (1947).

$\mathrm{C}-\mathrm{T}$
$\mathrm{Pi}=-----\mathrm{X} 100$

Where, 
$\mathrm{C}=$ Radial growth in control $(\mathrm{mm})$

$\mathrm{T}=$ Radial growth diameter in treatment

\section{Paper towel method}

The infected seeds of varieties SG-99 and M522 were treated with six fungicides by soaking in solution of fungicides for 8 hours to evaluate the effect of different seed treatments on germination and seedling vigour by paper towel method. The fungicide solutions were made with concentrations of $0.30,0.15,0.10$, $0.20,0.40$ and 0.30 per cent for mancozeb, tebuconazole, azoxystrobin, carbendazim, carbendazim + mancozeb and carboxin + thiram, respectively. The infected seeds were procured during Kharif 2016 from two groundnut varieties SG-99 and M-522 showing typical collar rot symptoms. Two types of controls were kept viz., infected seed with no seed treatment and apparently healthy seed with no seed treatment. Two sheets of paper towel were wetted by distilled water, leaving a $3 \mathrm{~cm}$ margin.

Twenty five seeds were kept on it equidistantly in five rows each containing five seeds and sheet was covered with another moistened paper towel. Then paper towel was rolled, wrapped in wax paper and tied by rubber band. They were incubated at $28 \pm 2$ ${ }^{\circ} \mathrm{C}$. Occasionally the sheets were kept moist.

Three replications were kept under each treatment. After 14 days sheets were opened to count number of normal seedlings, mortality (\%) and seed rots (\%). The categorization of normal seedlings, mortality $(\%)$ and seed rots (\%) was done as described by Khare and Bhale (2000).

Data were recorded in terms of per cent germination, seedling length, seedling dry weight, vigour index length and vigour index mass using the following formulas:
Germination (\%)

No. of normal seedlings

$=-\times 100$

Total seeds sown

Seedling length $=$ Average length $(\mathrm{cm})$ of 10 normal seedlings on the day of final count (after 14 days)

Seedling dry weight $=$ Average weight $(\mathrm{g})$ of 10 seedlings excluding the cotyledons after oven drying at $100^{\circ} \mathrm{C}$ for 24 hours

Vigour index length $=$ Germination $(\%) \times$ Seedling length $(\mathrm{cm})$

Vigour mass $=$ Germination $(\%) \times$ Seedling dry weight (g)

\section{Results and Discussion}

Evaluation of six fungicides were tested in laboratory by two methods namely poisoned food technique and paper towel method in Oilseed Plant Pathology Laboratory, Department of Plant Breeding and Genetics.

\section{Poisoned food technique}

Data with respect to inhibition of mycelia growth of A. niger of six different fungicides were recorded and results are presented in Table 1 and Fig 1. Data from the table revealed that, the efficacy of different fungicides, concentrations and their effect on the percent inhibition of mycelial growth of $A$. niger differed significantly. Among the test non-systemic fungicides, mancozeb was the most superior against $A$. niger as it provided the 56.38 per cent growth inhibition at 500 $\mu \mathrm{g} / \mathrm{ml}$. Singh and Singh (2006) reported the 100 per cent inhibition of the A. flavus at higher concentration $(1000 \mu \mathrm{g} / \mathrm{ml})$ of mancozeb. Similar results were also obtained by Sharma et al., (2012). Among the test systemic fungicides, tebuconazole proved to 
be the most effective by providing maximum mean per cent inhibition $(93.04 \%)$ of colony growth followed by azoxystrobin $(85.00 \%)$ (Plate 1). Tebuconazole at the concentration of 25, 50, 100 and $200 \mu \mathrm{g} / \mathrm{ml}$ completely (100\%) inhibited the colony growth of $A$. niger. However, azoxystrobin gave complete inhibition at concentrations of 100 and 200 $\mu \mathrm{g} / \mathrm{ml}$. Results are in accordance with those reported by Raju and Naik (2006). They studied the $100 \%$ inhibition in the radial growth of $A$. niger with the fungicide tebuconazole at recommended and half the recommended concentrations. Nathawat and Partap (2014) also recorded complete inhibition of mycelial growth of A. niger by tebuconazole at concentration of 100 to 1000 $\mu \mathrm{g} / \mathrm{ml}$. Among the two test combiproduct fungicides, carbendazim $25 \%+$ mancozeb $50 \%$ (Sprint) was proved to more effective by providing maximum mean per cent inhibition (58.93\%). Sheth and Patil (2010) noted complete inhibition of mycelia growth of $A$. niger infecting citrus fruits by treating with carbendazim + mancozeb at 500 and 1000 $\mu \mathrm{g} / \mathrm{ml}$ concentration. Kumari et al., (2016) also obtained similar results. While, carboxin $37.5+$ thiram 37.5 (vitavax power) gave mean colony growth inhibition of 49.67 per cent. Kumari et al., (2016) found 65.80 per cent growth inhibiton of $A$. niger with carboxin $37.5+$ thiram 37.5 (vitavax power).

In our present studies, 100 per cent inhibition in the radial growth of $A$. niger culture was obtained with two fungicides namely tebuconazole and azoxystrobin at $100 \mu \mathrm{g} / \mathrm{ml}$ concentration while carbendazim $25 \%+$ mancozeb $50 \%$ (Sprint) also gave good inhibition (94.38\%) of $A$. niger at $200 \mu \mathrm{g} / \mathrm{ml}$ concentration.

\section{Paper towel method}

Effect of six fungicides as seed treatment was evaluated for germination, seedling length, dry weight, vigour index length and vigour index mass on groundnut varieties SG-99 and M522. The results are given in Table 2 . Significant variation with respect to per cent germination was recorded in different seed treatments. Among various chemicals, the maximum germination was observed in case of carbendazim 25\% + mancozeb $50 \%$ (Sprint) in both the varieties SG-99 (96.33\%) and M-522 $(88.33 \%)$ followed by carboxin $37.5 \%$ + thiram $37.5 \%$ (Vitavax power). Seed treatments with carbendazim $25 \%+$ mancozeb $50 \%$ (Sprint) and carboxin $37.5 \%+$ thiram $37.5 \%$ (Vitavax power) were significantly superior over control (infected seeds) in respect of their effectiveness in increasing seed treatment. However, these two chemical seed treatments did not differ significantly from each other. Similar results were reported by Johnson and Subramanyam (2010). They observed that Vitavax power increased the seed germination significantly over other treatments and control. Likewise, Singh et al., (2004) proved that the thiram increased seed germination and vigour of the groundnut seedlings.

The effect of various test seed treatments on seedling length, dry weight, vigour index length and vigour index mass is presented in Table 2. The seedling length (root length + shoot length) was increased significantly by carbendazim 25\% + mancozeb 50\% (Sprint) and carboxin $37.5 \%$ + thiram $37.5 \%$ (Vitavax power) over all other treatments with nonsignificant difference among them for both the varieties. In treatment done with Sprint, the seedling length was $24.13 \mathrm{~cm}$ (SG-99) and $20.12 \mathrm{~cm}$ (M-522) and in Vitavax power seedling length was $23.80 \mathrm{~cm}$ (SG-99) and $19.51 \mathrm{~cm}$ (M-522). While seedling length of seed treatment with mancozeb was at par with the infected control. Shivpuri et al., (2011) observed that Vitavax power improved the shoot length of groundnut seedlings over the other treatments and control. 
Table.1 Evaluation of different fungicides against A. niger under in vitro conditions by poisoned food technique

\begin{tabular}{|c|c|c|c|c|c|c|c|c|c|c|}
\hline Systemicity & Fungicide & \multicolumn{9}{|c|}{ Per cent growth inhibition over check at different concentrations $\left(\mu \mathrm{g} \mathrm{ml} \mathbf{l}^{-1}\right)$} \\
\hline \multirow[t]{4}{*}{ Non-systemic } & & 5 & 10 & 25 & 50 & 100 & 200 & 400 & 500 & Mean \\
\hline & $\begin{array}{c}\text { Copper } \\
\text { Oxychloride }\end{array}$ & $\begin{array}{c}0.00 \\
(0.00)\end{array}$ & $\begin{array}{c}0.00 \\
(0.00)\end{array}$ & $\begin{array}{c}5.73 \\
(13.84)\end{array}$ & $\begin{array}{c}9.27 \\
(17.72)\end{array}$ & $\begin{array}{c}13.45 \\
(21.51)\end{array}$ & $\begin{array}{c}21.22 \\
(27.42)\end{array}$ & $\begin{array}{c}32.07 \\
(34.48)\end{array}$ & $\begin{array}{c}40.70 \\
(39.62)\end{array}$ & 15.30 \\
\hline & Mancozeb & $\begin{array}{c}9.23 \\
(17.68)\end{array}$ & $\begin{array}{c}12.60 \\
(20.78)\end{array}$ & $\begin{array}{c}18.86 \\
(25.73)\end{array}$ & $\begin{array}{c}23.27 \\
(28.83)\end{array}$ & $\begin{array}{c}28.33 \\
(32.15)\end{array}$ & $\begin{array}{c}33.27 \\
(35.21)\end{array}$ & $\begin{array}{c}48.16 \\
(43.93)\end{array}$ & $\begin{array}{c}56.38 \\
(48.65)\end{array}$ & 28.76 \\
\hline & Mean & 4.61 & 6.30 & 12.29 & 16.27 & 20.89 & 27.24 & 40.11 & 48.54 & \\
\hline \multirow[t]{4}{*}{ Systemic } & Tebuconazole & $\begin{array}{c}73.88 \\
(59.24)\end{array}$ & $\begin{array}{c}84.34 \\
(66.66)\end{array}$ & $\begin{array}{c}100 \\
(89.96)\end{array}$ & $\begin{array}{c}100 \\
(89.96)\end{array}$ & $\begin{array}{c}100 \\
(89.96)\end{array}$ & $\begin{array}{c}100 \\
(89.96)\end{array}$ & - & - & 93.04 \\
\hline & Azoxystrobin & $\begin{array}{c}57.77 \\
(49.45)\end{array}$ & $\begin{array}{c}69.56 \\
(56.49)\end{array}$ & $\begin{array}{c}87.14 \\
(68.96)\end{array}$ & $\begin{array}{c}95.54 \\
(77.78)\end{array}$ & $\begin{array}{c}100 \\
(89.96)\end{array}$ & $\begin{array}{c}100 \\
(89.96)\end{array}$ & - & - & 85.00 \\
\hline & Carbendazim & $\begin{array}{c}11.25 \\
(19.59)\end{array}$ & $\begin{array}{c}20.47 \\
(26.89)\end{array}$ & $\begin{array}{c}31.05 \\
(33.85)\end{array}$ & $\begin{array}{c}43.61 \\
(41.31)\end{array}$ & $\begin{array}{c}67.83 \\
(55.42)\end{array}$ & $\begin{array}{c}82.27 \\
(65 . .07)\end{array}$ & - & - & 42.74 \\
\hline & Mean & 47.63 & 58.12 & 72.73 & 79.72 & 89.27 & 94.09 & - & - & \\
\hline \multirow[t]{3}{*}{$\begin{array}{l}\text { Combination } \\
\text { (Systemic and } \\
\text { Non-systemic) }\end{array}$} & $\begin{array}{c}\text { Sprint } \\
\text { (mancozeb } 50 \\
+ \text { carbendazim } \\
\text { 25) }\end{array}$ & $\begin{array}{c}19.86 \\
(26.45)\end{array}$ & $\begin{array}{c}29.73 \\
(33.03)\end{array}$ & $\begin{array}{c}52.78 \\
(46.57)\end{array}$ & $\begin{array}{c}74.52 \\
(59.66)\end{array}$ & $\begin{array}{c}82.31 \\
(65.10)\end{array}$ & $\begin{array}{c}94.38 \\
(76.26)\end{array}$ & - & - & 58.93 \\
\hline & $\begin{array}{l}\text { Vitavax power } \\
\text { (carboxin } 37.5 \\
+ \text { thiram } 37.5 \text { ) }\end{array}$ & $\begin{array}{c}14.31 \\
(22.22)\end{array}$ & $\begin{array}{c}24.37 \\
(29.57)\end{array}$ & $\begin{array}{c}38.88 \\
(38.56)\end{array}$ & $\begin{array}{c}61.12 \\
(51.40)\end{array}$ & $\begin{array}{c}72.77 \\
(58.52)\end{array}$ & $\begin{array}{c}86.24 \\
(68.20)\end{array}$ & - & - & 49.61 \\
\hline & Mean & 17.08 & 27.05 & 45.83 & 67.82 & 77.54 & 90.31 & - & - & \\
\hline $\begin{array}{l}\text { Non systemic: } \\
\mathrm{CD}(\mathrm{p}=0.05) \\
\text { Fungicide }=0.40 \\
\text { Concentrations }=0.79 \\
\text { Fungicide } \mathrm{x} \text { Concentra }\end{array}$ & 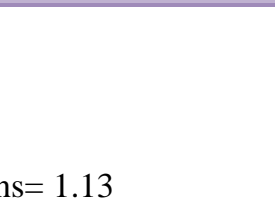 & $\begin{array}{l}\text { Syste } \\
\text { CD }(\mathrm{p} \\
\text { Fungi } \\
\text { Conc } \\
\text { Fung }\end{array}$ & $\begin{array}{l}: \\
05) \\
=0.57 \\
\text { ations }=0 . \\
\times \text { Concen }\end{array}$ & ons $=1.39$ & $\begin{array}{r}\text { Com } \\
\text { CD }(1 \\
\text { Fung } \\
\text { Conc } \\
\text { Fungi }\end{array}$ & $\begin{array}{l}\text { ion (Syst } \\
=0.67\end{array}$ & and Non : & & & \\
\hline
\end{tabular}


Table.2 Effect of seed treatment with fungicides on germination and vigour of groundnut seed evaluated by paper towel method

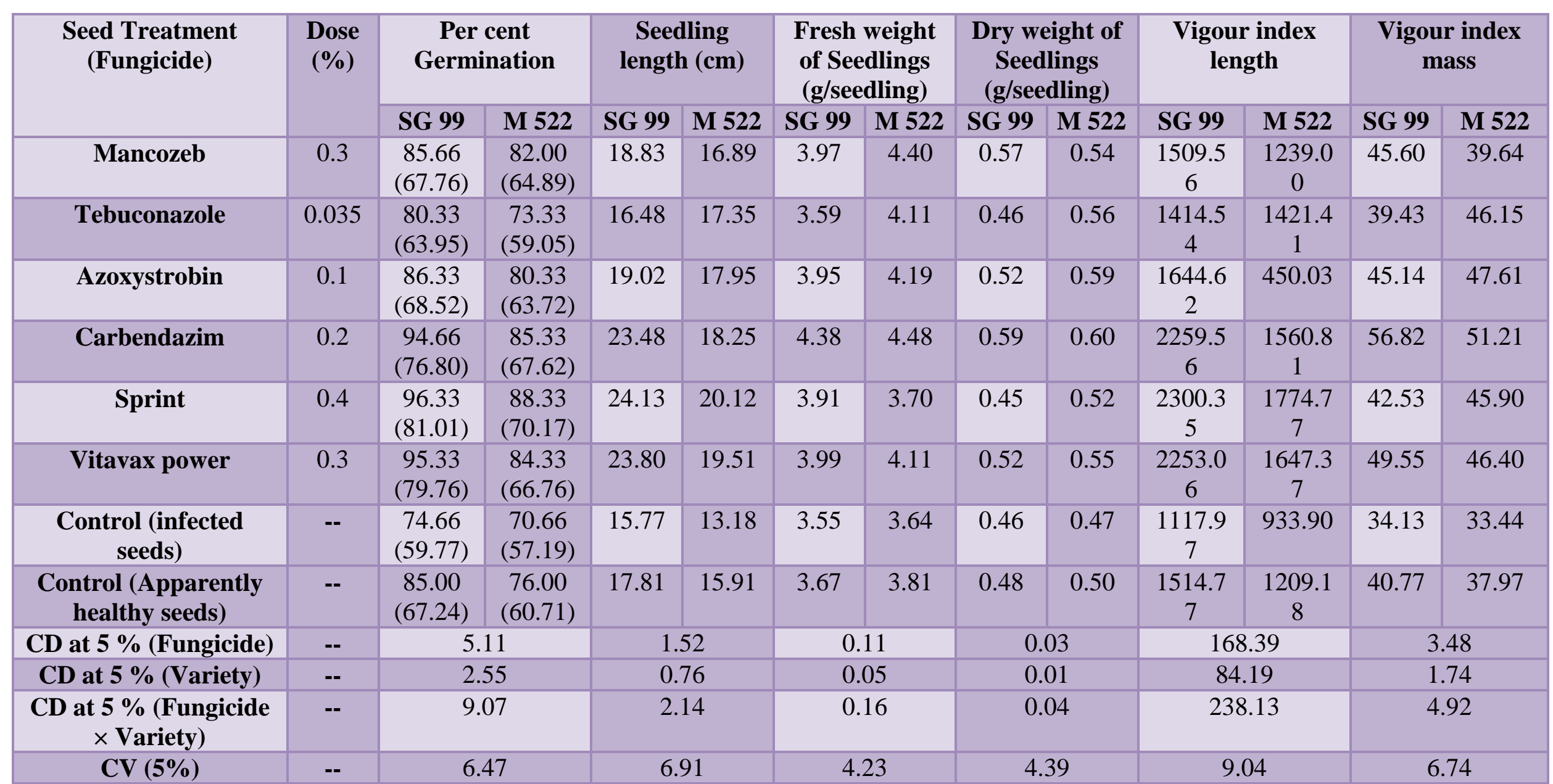

Figures in parentheses are angular transformed values 
Table.3 Germination status of groundnut seeds treated with different fungicides using paper towel method

\begin{tabular}{|c|c|c|c|c|c|c|c|}
\hline \multirow[t]{2}{*}{ Seed treatment } & \multirow[t]{2}{*}{$\begin{array}{l}\text { Dose } \\
(\%)\end{array}$} & \multicolumn{2}{|c|}{$\begin{array}{c}\text { Normal seedlings } \\
(\%)\end{array}$} & \multicolumn{2}{|c|}{ Mortality (\%) } & \multicolumn{2}{|c|}{ Seed rots $(\%)$} \\
\hline & & SG 99 & M 522 & SG 99 & M 522 & SG 99 & M 522 \\
\hline Mancozeb & 0.3 & $\begin{array}{c}48.67 \\
(44.22)\end{array}$ & $\begin{array}{c}47.67 \\
(43.65)\end{array}$ & $\begin{array}{c}37.33 \\
(37.65)\end{array}$ & $\begin{array}{c}38.67 \\
(38.43)\end{array}$ & $\begin{array}{c}14.67 \\
(22.51)\end{array}$ & $\begin{array}{l}17.33 \\
(24.59)\end{array}$ \\
\hline Tebuconazole & 0.035 & $\begin{array}{c}88.00 \\
(69.70)\end{array}$ & $\begin{array}{c}74.67 \\
(59.76)\end{array}$ & $\begin{array}{c}8.00 \\
(16.42)\end{array}$ & $\begin{array}{c}10.67 \\
(19.05)\end{array}$ & $\begin{array}{c}4.00 \\
(11.53)\end{array}$ & $\begin{array}{c}12.00 \\
(20.26)\end{array}$ \\
\hline Azoxystrobin & 0.1 & $\begin{array}{l}76.00 \\
(60.64)\end{array}$ & $\begin{array}{c}73.33 \\
(58.89)\end{array}$ & $\begin{array}{l}14.00 \\
(21.96)\end{array}$ & $\begin{array}{c}14.67 \\
(22.51)\end{array}$ & $\begin{array}{c}5.33 \\
(13.35)\end{array}$ & $\begin{array}{c}14.67 \\
(22.51)\end{array}$ \\
\hline Carbendazim & 0.2 & $\begin{array}{c}54.67 \\
(47.66)\end{array}$ & $\begin{array}{c}52.00 \\
(46.13)\end{array}$ & $\begin{array}{c}22.67 \\
(28.42)\end{array}$ & $\begin{array}{c}28.00 \\
(31.94)\end{array}$ & $\begin{array}{l}18.67 \\
(25.59)\end{array}$ & $\begin{array}{c}26.67 \\
(31.08)\end{array}$ \\
\hline Sprint & 0.4 & $\begin{array}{c}73.33 \\
(58.89)\end{array}$ & $\begin{array}{c}65.33 \\
(53.91)\end{array}$ & $\begin{array}{l}16.00 \\
(23.57)\end{array}$ & $\begin{array}{l}18.67 \\
(25.59)\end{array}$ & $\begin{array}{c}5.33 \\
(13.35)\end{array}$ & $\begin{array}{l}16.00 \\
(23.57)\end{array}$ \\
\hline Vitavax power & 0.3 & $\begin{array}{l}70.67 \\
(57.18)\end{array}$ & $\begin{array}{c}52.00 \\
(46.13)\end{array}$ & $\begin{array}{l}21.33 \\
(27.50)\end{array}$ & $\begin{array}{l}21.33 \\
(27.50)\end{array}$ & $\begin{array}{c}13.33 \\
(21.41)\end{array}$ & $\begin{array}{l}20.00 \\
(26.55)\end{array}$ \\
\hline Control (infected seeds) & -- & $\begin{array}{l}22.67 \\
(28.42)\end{array}$ & $\begin{array}{c}17.33 \\
(24.59)\end{array}$ & $\begin{array}{c}52.00 \\
(46.13)\end{array}$ & $\begin{array}{c}53.33 \\
(46.89)\end{array}$ & $\begin{array}{c}25.33 \\
(30.21)\end{array}$ & $\begin{array}{c}29.33 \\
(32.78)\end{array}$ \\
\hline $\begin{array}{c}\text { Control (Apparently } \\
\text { healthy seeds) }\end{array}$ & -- & $\begin{array}{c}46.67 \\
(43.07)\end{array}$ & $\begin{array}{c}30.67 \\
(33.61)\end{array}$ & $\begin{array}{c}38.67 \\
(38.43)\end{array}$ & $\begin{array}{c}45.33 \\
(42.31)\end{array}$ & $\begin{array}{c}14.67 \\
(22.51)\end{array}$ & $\begin{array}{l}24.00 \\
(29.32)\end{array}$ \\
\hline CD at $5 \%$ (Fungicide) & -- & \multicolumn{2}{|c|}{3.15} & \multicolumn{2}{|c|}{2.84} & \multicolumn{2}{|c|}{2.91} \\
\hline CD at $5 \%$ (Variety) & -- & \multicolumn{2}{|c|}{1.57} & \multicolumn{2}{|c|}{1.42} & \multicolumn{2}{|c|}{1.46} \\
\hline $\begin{array}{c}\text { CD at } 5 \% \text { (Fungicide } \times \\
\text { Variety) }\end{array}$ & -- & \multicolumn{2}{|c|}{4.46} & \multicolumn{2}{|c|}{4.01} & \multicolumn{2}{|c|}{4.12} \\
\hline CV $(5 \%)$ & -- & \multicolumn{2}{|c|}{5.53} & \multicolumn{2}{|c|}{7.82} & \multicolumn{2}{|c|}{10.72} \\
\hline
\end{tabular}

Figures in parentheses are angular transformed values

Fig.1 Invitro evaluation of different fungicides against Aspergillus niger by poisoned food technique

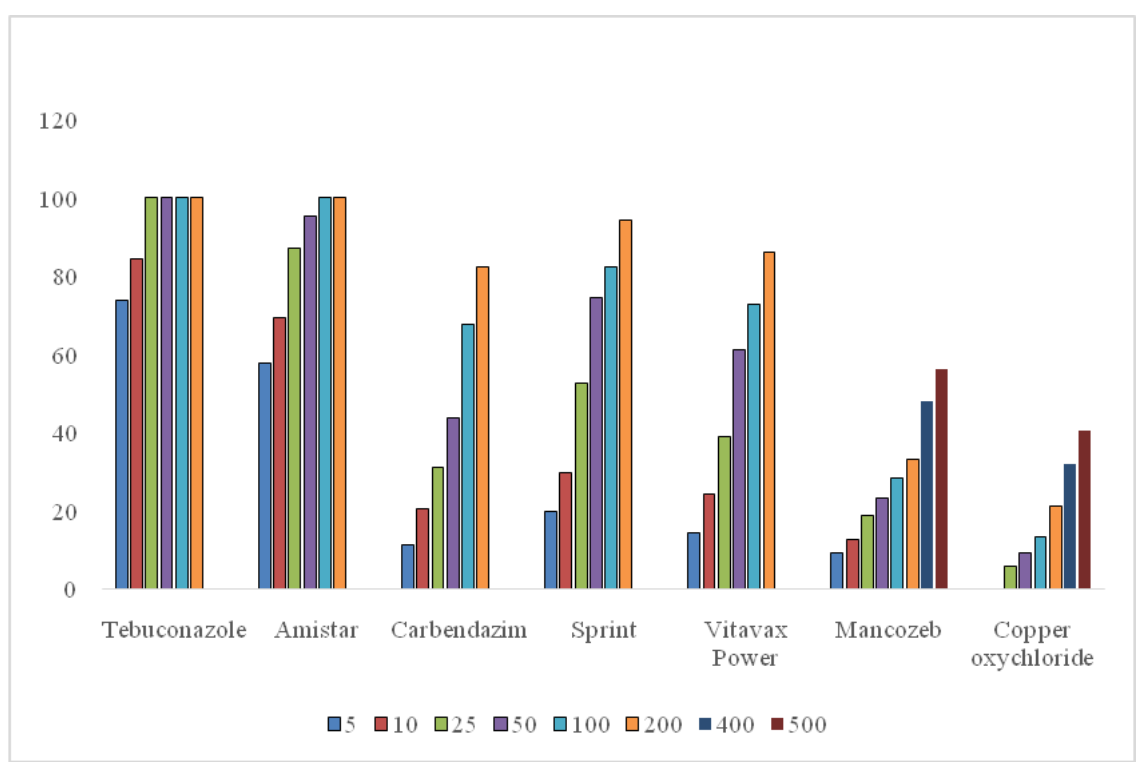


Fig.2 Germination status (\%) of groundnut seeds (variety SG-99) treated with different fungicides using paper towel method

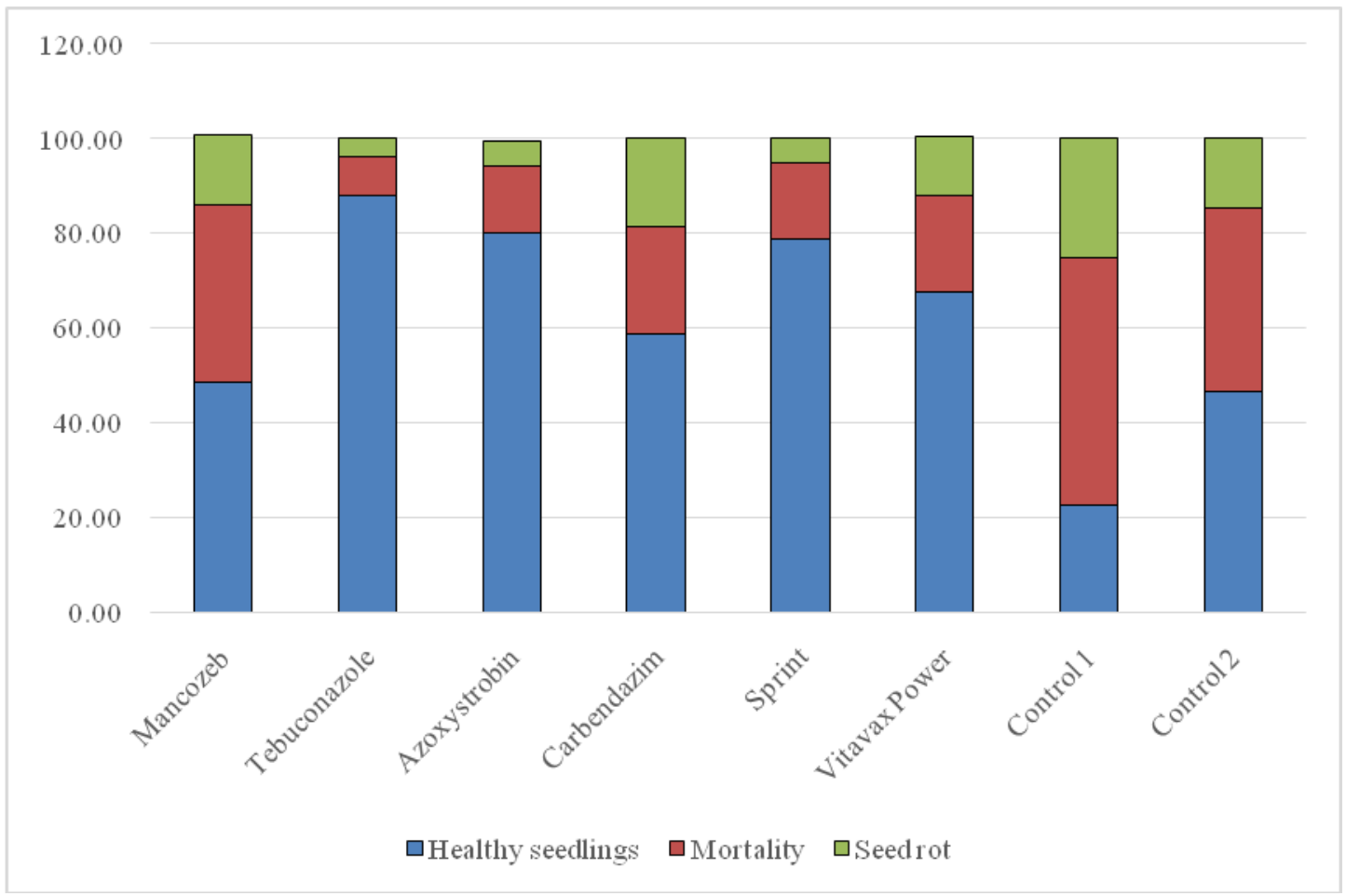

Fig.3 Germination status (\%) of groundnut seeds (variety M-522) treated with different fungicides using paper towel method

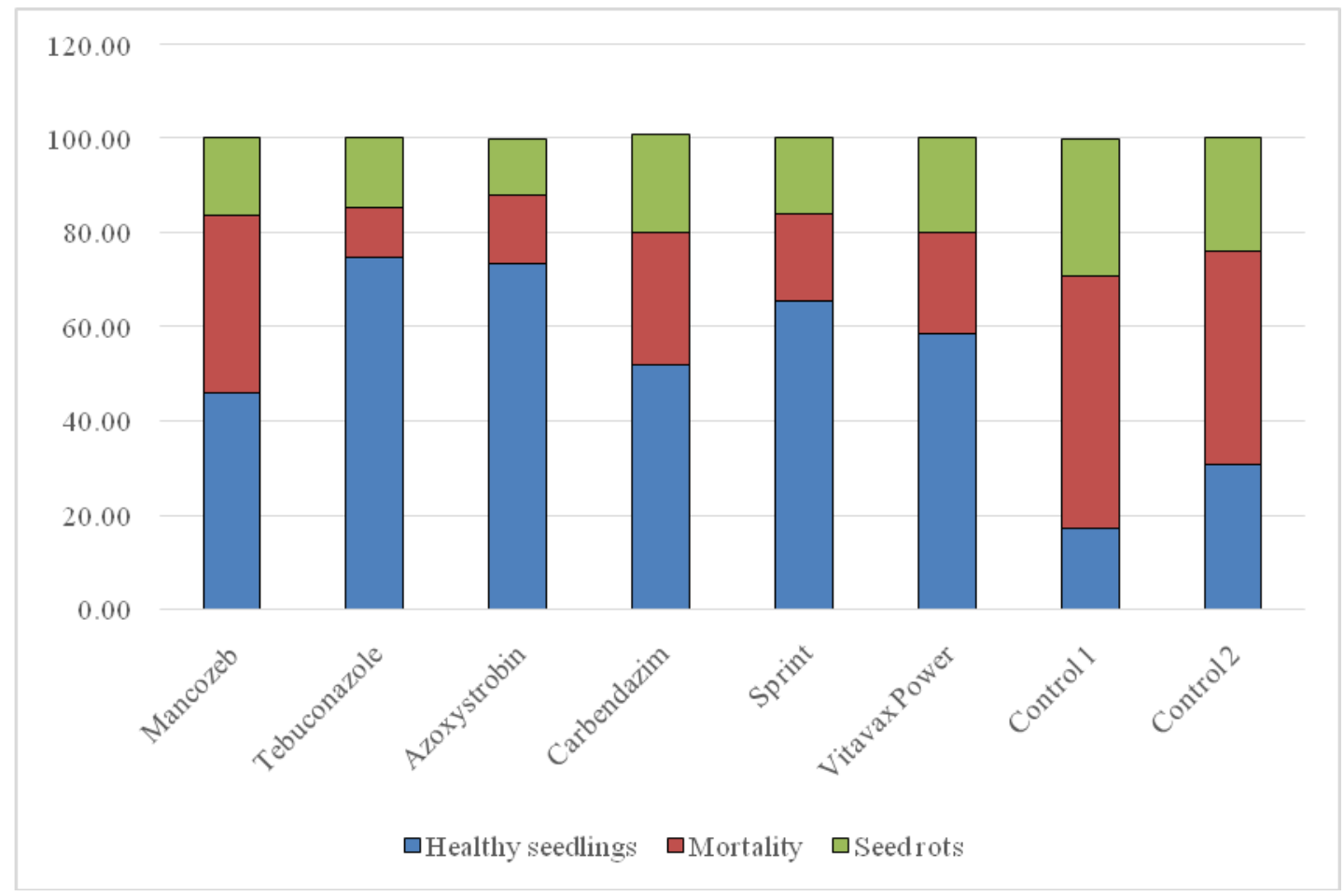


Plate.1 Colony growth inhibition of Aspergillus niger by (a) Tebuconazole and (b) Azoxystrobin

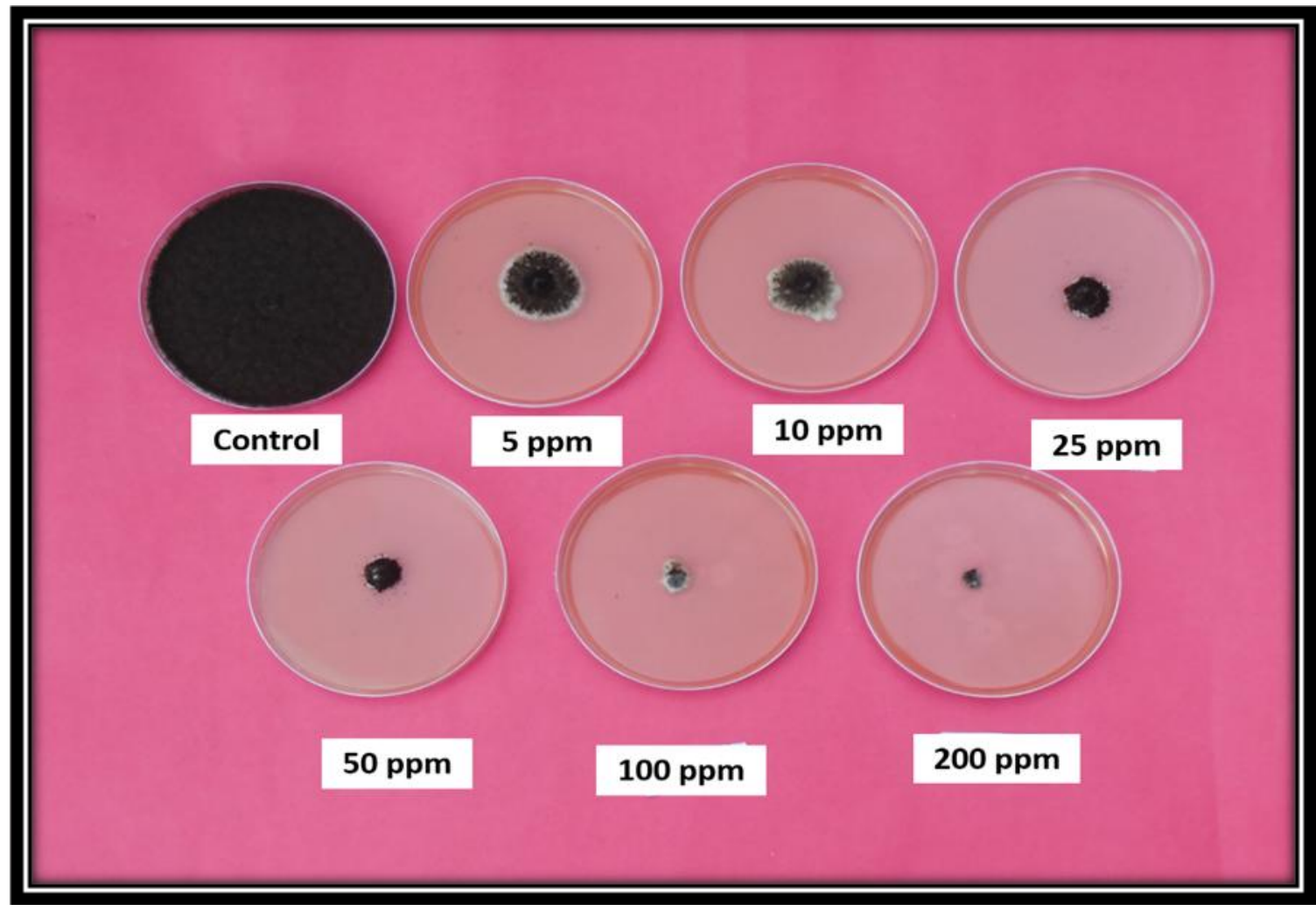

Plate.2 Vigour of groundnut seedlings (a) seed treatment with tebuconazole (b) untreated control using paper towel method

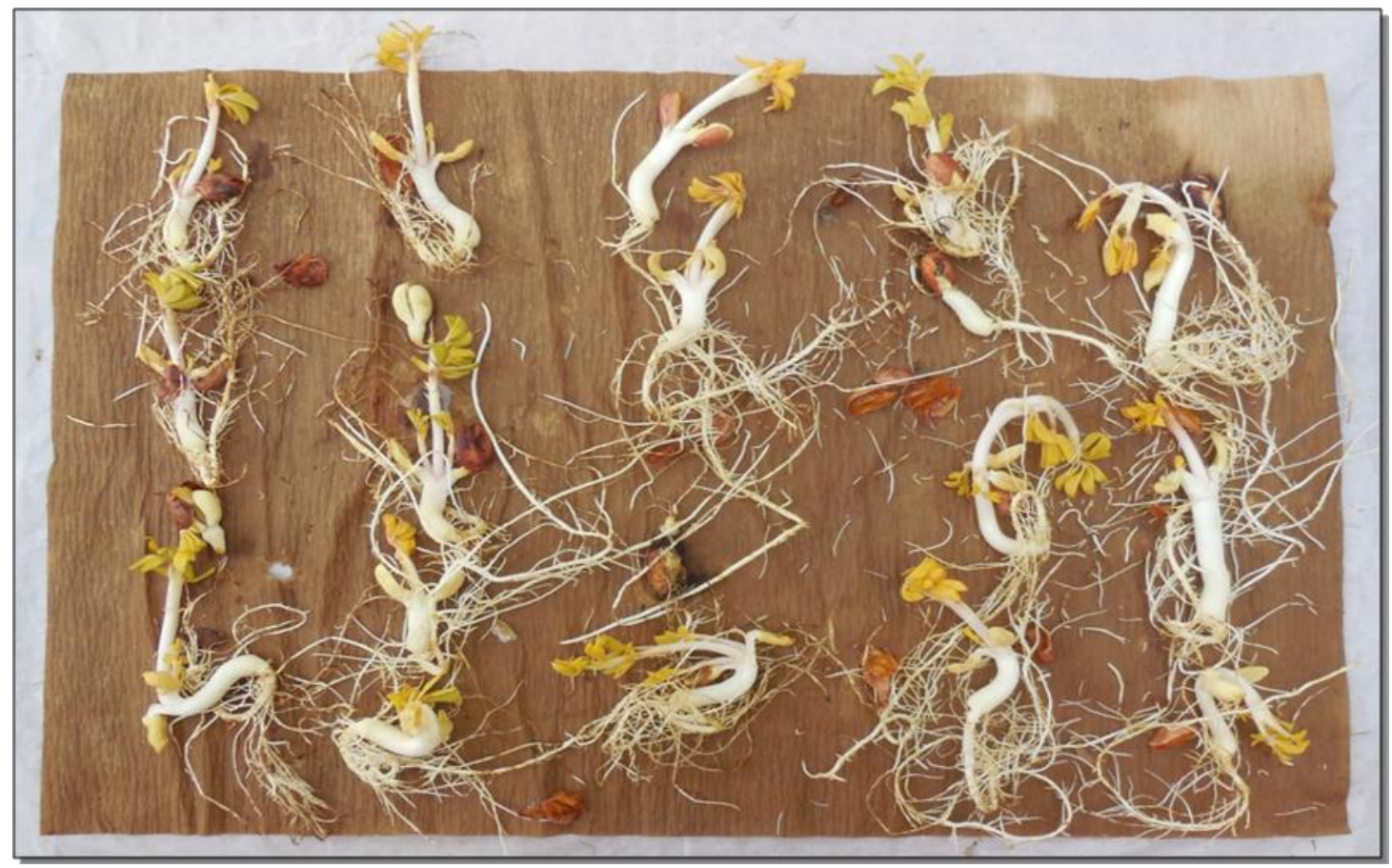




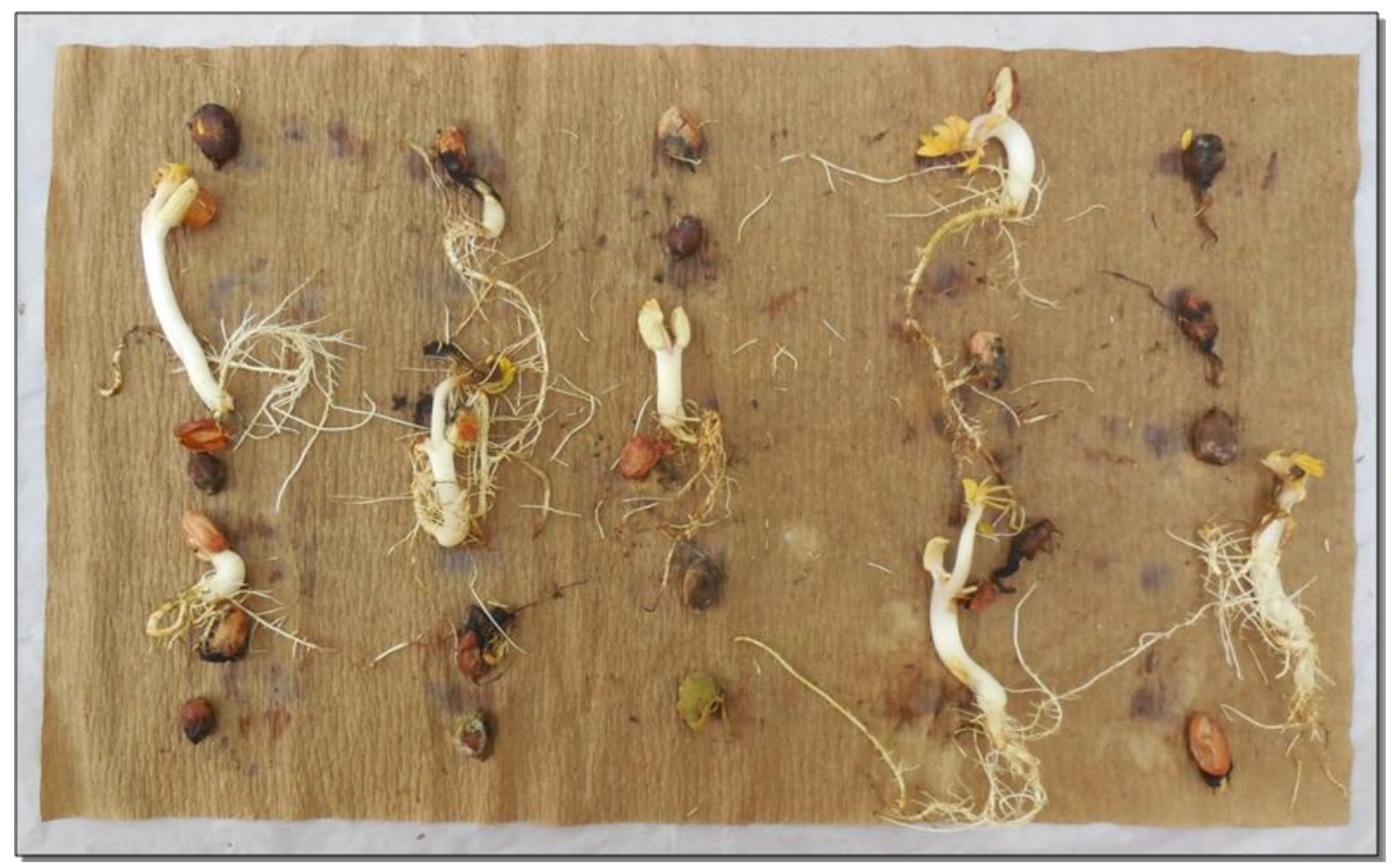

The vigour index in terms of length $(\mathrm{cm} /$ seedling) and dry weight $(\mathrm{g} / \mathrm{seedling})$ of seedlings was calculated to find effect of seed treatment on seedling vigour. The vigour index length was significantly higher in case of Sprint (2300.35 in SG-99 and 1774.77 in M-522) and Vitavax power (2253.06 in SG-99 and 1774.77 in M-522) over all other treatments with non-significant difference among them for both the varieties. The vigour index mass was significantly higher in case of carbendazim (56.82 for SG-99 and 51.21 for M-522) and Vitavax power over all other treatments with non-significant difference among them for both the varieties. Devi and Parsad (2009) observed that seed treatment with captan improved the growth parameters like yield and biomass production that was due to the increase in vigour of the seedlings. Shivpuri et al., (2011) observed that Vitavax power improved the shoot length which ultimately gave the maximum vigour index length of groundnut seedlings over the other treatments and control.
The germination status of the chemically treated groundnut seeds (Fig 2 and 3) after 14 days of incubation in paper towel sheets is summarized in Table 3. The maximum percentage of healthy seedlings in variety SG$99(88.00 \%)$ and $\mathrm{M}-522(74.67 \%)$ was recorded in case of tebuconazole (Plate 2). The observations for the mortality (\%) showed reverse trend, where minimum per cent mortality was recorded in tebuconazole in variety SG-99 $(8.00 \%)$ and M-522 (10.67 \%) followed by azoxystrobin and Sprint. The minimum percentage of seed rots were found in seed treatments with tebuconazole $(4.00 \%$ in SG-99 and $12.00 \%$ in M-522) and azoxystrobin $(5.33 \%$ in SG-99 and $14.67 \%$ in M-522) for both the varieties. Johnson and Subramanyam (2010) evaluated the different fungicides and found that seed treatment with tebuconazole showed minimum collar rot occurrence. The observations summarized in Table 2 and 3 and Figures 2 and 3 led to the conclusion that the collar rot diseases has a marked effect on seed germination and seedling vigour. Seed treatment with 
tebuconazole was the best followed by azoxystrobin and carbendazim 25\% + mancozeb $50 \%$ (Sprint) to increase seed germination and seedling vigour both.

The above results from both the experiments revealed that tebuconazole was the best followed by azoxystrobin and carbendazim $25 \%+$ mancozeb $50 \%$ (Sprint) to control the collar rot of groundnut caused by A. niger.

\section{References}

Anonymous (2015) Area, production and average yield of groundnut in India. http://www.indiastat.com.

Aulakh K S and Sandhu R S, (1970 Reaction of groundnut varieties against Aspergillus niger.Plant Disease Res 54: 337.

Chohan J S (1965) Collar rot of groundnut (ArachishypogaeaL.) caused by $A$. nigervan Tieghem and $A$. pulvarulentus (Mc Alpine) Thom in the Punjab. J Res Punjab Agricultural University 3: 25-33.

Devi M C and Prasad R D (2009) Biointensive management of collar rot of groundnut caused by Aspergillus niger. J of Biological Control 23(1): 21-24.

Johnson M and Subramanyam K (2010) Evaluation of different fungicides against seed and soil borne diseases of groundnut. Ind J Pl Protec38: 80-83.

Joshi D H (1969) Studies on the seed microflora of groundnut, cotton, bajra, wheat and sesame under Gujarat condition. M.Sc (Agri).Thesis. Gujarat Agricultural University, SardarKrishinagar, Dantiwada.

Khare D and Bhale M S (2000) Seed technology. Pp-260, Milton back company, Dehradun, India.

Kumari M, Singh M, Godika S, Choudhary S and Sharma J (2016) Effect of different fungicides, plant extracts on incidence and varietal screening against collar rot of groundnut (Arachis hypogea L.) caused by Aspergillus niger Van Tiegham International $J$ Life Sci11(4):2835-2839.

Nathawat B D S and Partap M (2014) Evaluation of fungicides, botanicals and Trichoderma spp against collar rot of groundnut (Arachis hypogaeaL.) caused by Aspergillus niger Van. Tiegham. Ann Pl ProtecSci 22: 38285.

Nene Y L and Thapliyal P N (1993) Fungicides in Plant Disease Control. Oxford and IBH Publishing House, New Delhi. Pp-163.

Parjapati B K, Patil R K and Alaka (2016) Bio-efficacy of fungicides in management of black mould (Aspergillus niger) of onion. Int J Agri Sci Res 6(4):155-60.

Raju K and Naik M K (2006) Effect of preharvest spray of fungicides and botanicals on storage diseases of onion. Indian Phytopath 59(2): 133141.

Sharma D P, Chaudhary L N, Saxena A K and Shashi B S (2012) Isolation and characterization of Bifenthrin degrading fungal isolates from acclimatized soil. Ann Pl ProtecSci20: 172-176.

Sheth D B and Patil R K (2010) Bio-efficacy of fungicides and botanicals in management of Aspergillus fruit rot of lime (Citrus aurantifolia) in vitro and in vivo. J P Dis Sci5 (1):90-94.

Shivpuri A, Mali S N and Gangwar R K (2011) Bioefficacy of carboxin 37.50+ thiram $37.50 \%$ (Vitavax power) against collar rot of groundnut as seed dresser. Pestology 5:11-13.

Singh P C and Singh D (2006)In vitro evaluation of fungicides against Alternaria alternata. Ann Pl Protec Sci 14:500-502. 
Singh S D, Rawal P and Bhargava N K (2004) Pathogenic potential and control of seed mycoflora of groundnut (Arachis hypogaea). $\mathrm{J}$ Mycol Pl Pathol 34(2):687.

Subrahmanyam P, Mehan V K, Nevill D J and MacDonald D (1980) Research on Fungal Diseases of Groundnut. ICRISAT. In: A Proceeding of an International Workshop on Groundnut.
ICRISAT, Patancheru, A.P. India, pp: 189-197.

Vincent J M (1947) Distortion of fungal hyphae in the presence of certain inhibitors. Nature, Pp-850.

Wani M A and Kuruchave V (2004) Effect of garlic bulb extract and buffalo unine on growth of Aspigillus niger and A. flavus. Ann Pl Protec Sci 12: 221-22.

\section{How to cite this article:}

Amritpal Singh Sekhon, Prabhjodh Singh Sandhu, Pankaj Sharma and Rakesh Belludi. 2019. In Vitro Evaluation of Fungicides against Aspergillus niger causing Collar Rot Disease in Groundnut (Arachis hypogaea L.). Int.J.Curr.Microbiol.App.Sci. 8(11): 908-919.

doi: https://doi.org/10.20546/ijcmas.2019.811.106 